\title{
Analysis on the Opportunities and Challenges of Unilever's Differentiated Competition by Using SWOT and PEST
}

\author{
Yiming Cheng ${ }^{1, *}$
}

\author{
${ }^{1}$ Westa College, Southwest University, Chongqing 400715, China \\ *Corresponding author. Email: 18625887306@163.com
}

\begin{abstract}
The outbreak of Covid-19 in 2020 has brought downturn to the global economy and many companies went bankrupt during the epidemic. However, according to Unilever's financial report for the first half year, its sales fell only by $\mathbf{1 . 6 \%}$ and its financial situation is still stable. The reason for it is not only for Unilever's action of taking Covid-19 as normalization, but also for its differentiation strategies, which make Unilever a competitive enterprise when the consumer products are in demand in Covid-19. Through the literature research method, this article uses the combination of SWOT (strengths, weaknesses, opportunities and threats) and PEST (political, economic, social and technological factors) models to explore the internal and external environments of Unilever in 2020, and concludes that under the multiple impacts of the external environment, Unilever still has great opportunities to make development relying on its own excellent internal conditions.
\end{abstract}

\section{Keywords: Unilever, differential competitive advantages, SWOT, PEST, opportunities and challenges}

\section{INTRODUCTION}

There is almost no barrier to enter into the consumer product industry, so there are a large number of competitors, even each country has its own wellestablished companies. However, Unilever, as an Anglo-Dutch company, operates over 400 products in 190 countries around the world, and against the background of the backdrop of global economy due to Covid-19, Unilever's sales decreased by only $1.6 \%$. The reason is that Unilever still strives to create a series of differentiation such as differentiation in price and product in such a low differential consumer product market. This article aims to analyze Unilever's internal and external environment by combining the SWOT and PEST models, and find out the opportunities and challenges on its differentiated competitive advantages that Unilever has faced in recent years, so as to give experience to the companies in such a highly competitive industry like consumer products.

\section{OVERVIEW OF UNILEVER}

In 1929, the Lever brothers signed an agreement with Margarine Unie to form Unilever. Today, Unilever is one of the world's largest consumer products companies, with more than 400 brands and a global reach of 2.5 billion people in 190 countries. These 400 brands are mainly divided into three main businesses around consumer products which are
Food\&Refreshment, Home Care and Beauty\&Personal Care.

The consumer products' industry is highly competitive and has a number of competitors. In personal care products markets, Unilever competes fiercely with Proctor \& Gamble and Colgate-Palmolive [1], and in the fabric conditioner market, Unilever competed with Comfort, Kuschelweich, Cajoline, Coccolino, Mimosin, Robijn, and Bamsoline [2].

\section{ANALYSIS OF THE EXTERNAL} ENVIRONMENT

\section{A. Political factors}

At present, the international environment is relatively peaceful and the political situation in various countries is relatively stable, which create a good environment for Unilever's development. However, the stagnation of Brexit is a key factor for Unilever's future development. Whether future free trade agreements between the UK and European countries will become harsh is still an uncertain factor.

Moreover, trading within different countries is also influenced by political environment. Different countries have different trade protection policies. For example, China has reduced tariffs in the consumer products in 2018 in order to expand its opening up and meet the demand for people. While the Trump administration has pursued a policy of trade protection, the US withdrew 
from the Trans-Pacific Partnership trade agreement on 23 January 2017, and an overly conservative trade policy gave a huge challenge for Unilever's growth in US.

In Europe and the US, Unilever is not only subject to the regulatory restrictions of the European Union and the US Food and Drug Administration, but also subject to the laws of the region in which it is located. And different countries have different laws. For example, the Norwegian authority relies on a regulatory framework which imposes strict restrictions on the operations of Unilever and requires the company to make concessions in return in order to let the purchase go ahead [3]. However, the strengthening of international patent law and the worldwide law is a great protection and opportunity for Unilever to continuously develop new products.

\section{B. Economic factors}

1) A downturn in global economic situation: The epidemic of Covid-19 has brought about a global economic downturn, and Unilever posting six-month sales of $€ 25.7$ billion, decreased by $1.6 \%$. However, Unilever's downward trend is very small compared to the $2.3 \%$ decline forecasting previously. Although the global economic downturn has had an impact on Unilever, the speed of Unilever dealing with Covid-19 and the level of decision-making have minimized its impact on Unilever. At the same time, the outbreak has brought some local consumer product companies on the brink of bankruptcy, which makes it a good opportunity for Unilever's takeover. What is more, during the epidemic, Unilever rushed to develop disinfection products to meet the increased market demand for disinfection products, which are $99.999 \%$ effective.

2) International exchange rate of the Pound and the Euro: Unilever's financial statements denominated in Euros. The progress of Brexit has stalled, but after Brexit, the exchange rate between the Pound and the Euro is bound to fluctuate considerably for some time. And actually, the fluctuations of the exchange rate of Pound did impact Unilever. In 2016, caused by Brexit referendum, the Pound fall by $16 \%$ compared with the dollar. Hence, Unilever's profits drop $21 \%$ when the cost of ice cream was denominated in US dollars and sold in UK [4].

\section{Social factors}

As people's standard of living improves, the demand for high-end grocery and cosmetics is increasing. And people pay more attention to health, which fits perfectly with Unilever's three main businesses, i.e. Home Care, Beauty \& Personal Care and Foods \& Refreshment. What is more, Unilever is expanding into higher-end product lines such as health management.
Simultaneously, with the continuous strengthening of environmental protection awareness, Unilever has discovered the inherent connection between environmental protection and corporate development and the connection is sustainable development. Unilever has implemented the sustainable development strategy, not only to achieve business growth but to enhance Unilever's positive influence in society. However, in recent years, in the consumer product industry, the growth of local companies in various countries has been fierce in order to satisfy consumer's demand and these newly developing companies are all competitors for Unilever. In an interview with the Financial Times, Paul Polman, the CEO of Unilever, said that "regional players" in emerging markets have become the company's most intense competitors, but he still believes that Unilever has long-term opportunities in these markets.

\section{Technology}

Unilever is actively promoting digital transformation and embracing innovation. In selecting suitable talent, Unilever uses artificial intelligence with HR specialists [5]. At the same time, with the development of the Internet, the use of digital media platform in Unilever promotes the integration with users and suppliers, which implies that there is no need for manual intervention in the input of transaction data, so it reduces paperwork and improves the accuracy of data [6].

\section{ANALYSIS OF CONDITIONS WITHIN UNILEVER}

\section{A. Financial capability}

Unilever's total assets are financially stable and increasing in line with the increase in operational requirement liabilities [7]. At the same time, Unilever has eight major financial-related departments including excellent finance team, supply chain finance and factory finance, and taxation [8], so they have strong financial management capabilities. However, according to financial analysis from 2012 to 2016, Unilever's solvency and liquidity are weak, and there is a potential debt risk [7].

\section{B. Organizational leadership}

Unilever's leadership growth profile is composed of the following three points:

- Establish a growth vision (growth is the key criterion for Unilever's employee behavior);

- Promote growth through implementation and motivate others to promote growth;

- Ensure employees commitment to growth.

As a global company, Unilever's leaders need to have a global version, according to the survey of Floris 
A. Maljers in 1992, Unilever's board members came from six different countries, with almost every operating company including expatriates [9]. And at present, Unilever's Executive Director Joanne Lu, Nils Andersen, the chairman of board, and other Board members have worked in different countries or for global companies, which is beneficial for Unilever's global development.

\section{Product marketing capabilities}

1) Centralized strategy and brand slimming: In the 1990s, Unilever had more than 2,000 brands, but sales continued to be sluggish. At that time, Unilever's global CEO Niall Fitzgerald decided to reform and eliminate some brands. In 2003, after a series of elimination and brand reorganization, the number of Unilever's brands was reduced to 400 and increased the influence of the core brand continuously. By 2008, $80 \%$ of Unilever's sales were provided by $20 \%$ of its core brands, greatly increasing Unilever's brand control capabilities [7].

2) Localization: As local people have a deeper understanding of local needs, at Unilever, team managers are responsible for identifying talent from local universities to be nurtured for "Indianisation", "Australianisation", "Brazilianisation", etc. [9] At the same time, Unilever continues to purchase local companies in order to reduce competition [10]. For example, in order to enter the US market, Unilever chose to acquire Cheseborough-Ponds, as $75 \%$ of Cheseborough-Ponds' products are sold in the US market. However, not every acquisition is successful. For example, its positioning overlapped with Unilever's own brand positioning. The acquisition of MEGAMAN toothpaste in China had been failed and finally the brand disappeared.

3) Low price strategy: In 2009, Unilever's CEO Paul Polman changed the predecessor's pricing strategy to drive greater sales at lower prices [11]. However, the low-price strategy cannot be sustained forever because too low profit margins will reduce the profitability of enterprises and cause vicious market competition.

4) Diverse product and brand portfolio: Unilever's product lines are long and deep. In China, there are six major brands that focus on shampoo and hair care products, including TRESemmé, Hazeline, Lux, Dove, Seedology and Clear. And the range of Hazeline is divided into six categories: Multi-Care Shampoo, Black Shine Oil Shine 2-in-1 Shampoo, Black Shine LongLasting Anti-Dandruff Shampoo, Multi-Care AntiDandruff Shampoo, Oil Control Long-Lasting AntiDandruff Shampoo and Conditioning Anti-Fall Shampoo. At the same time, Unilever's brand portfolio varies from country to country, with brands being added and subtracted to find the most suitable product mix.

\section{SWOT MATRIX}

The SWOT matrix has the following strengths, weaknesses, opportunities and threats. ("Table I")

TABLE I.

SWOT MATRIX

\begin{tabular}{|c|c|}
\hline $\begin{array}{l}\text { Strengths } \\
\text { Stable financial position and strong financial strength } \\
\text { Experienced leaders with globalization vision } \\
\text { Centralized brand strategy and strong brand control } \\
\text { Localization } \\
\text { Greater sales with lower price } \\
\text { Diverse product and brand portfolio }\end{array}$ & $\begin{array}{l}\text { Weaknesses } \\
\text { Weak solvency and liquidity } \\
\text { National brand killer and have many failed acquisitions } \\
\text { Vicious market competition caused by low price }\end{array}$ \\
\hline $\begin{array}{l}\text { Opportunities } \\
\text { The international environment is peaceful (Politics) } \\
\text { In some countries, like China, expand its opening up and decreased } \\
\text { taxes (Politics) } \\
\text { Limited by various laws of different countries (Politics) } \\
\text { Local business bankruptcy due to covid-19 (Economy) } \\
\text { Increased demand for high-end consumer products and cosmetics } \\
\text { (Society) } \\
\text { Increased environmental awareness (Society) } \\
\text { The development of the digital technology and the Internet } \\
\text { (Technology) }\end{array}$ & $\begin{array}{l}\text { Threats } \\
\text { Free trade agreements between the UK and European } \\
\text { countries is uncertain because of Brexit (Politics) } \\
\text { In some countries, like America, implement a conservative } \\
\text { trade policy (Politics) } \\
\text { Improvements to international patent law (Politics) } \\
\text { A global economic downturn due to Covid-19 (Economy) } \\
\text { Fluctuations of exchange rate between Pound and Euro is } \\
\text { uncertain. (Economy) } \\
\text { The rise of local companies (Society) }\end{array}$ \\
\hline
\end{tabular}

Unilever's opportunities and challenges coexist in the external environment. Although the international environment is generally peaceful, global companies, like Unilever, need to be prepared to actively respond to the uncertain situation of Brexit and the further US trade policy. Due to the different laws and regulations of different countries, Unilever is subject to different restrictions in different countries. The outbreak Covid-
19 in 2020 has caused the global economy to decline, but Unilever responded to the epidemic in time and seized the opportunity to do research to resist Covid-19, which reduced the impact of the epidemic on Unilever. The pull of social demand and the development of technology also have created opportunities for Unilever to further expand its operations. 
In the internal environment, Unilever's strengths are stronger than its weaknesses. Unilever tries to increase its sales through a variety of marketing methods. Coupled with a steady cash flow and a good brand image, Unilever has strong strengths. However, the increase in debt and the rise of local companies are still the weaknesses of Unilever in the business process, which cannot be ignored.

\section{OPPORTUNITIES AND CHALLENGES OF DIFFERENTIATION}

\section{A. Product differentiation}

Unilever does not just think of its products as profitmaking tools, but more importantly, it pursues the differentiation strategy in order to increase the organization's competitiveness [12]. Through market research for Unilever's ice cream brand Magnum in
Pakistan, it was found that compared with other ice creams, Magnum's quality and taste made it uniquely appealing for consumers [13]. However, actually while first foraying into developing countries, Unilever usually takes low-price strategy, such as Fair \& Lovely, as people in developing countries are often more concerned about the price of the products [14].

\section{B. Other differentiation}

In addition to the most important product differentiation, Unilever also makes differentiation in other parts. HUL, meets the different needs of its customers through customizing products and services [15], and Sagit, Unilever's food subsidiary in Italy, even subdivides its warehouses by geographic location and level, such as primary, secondary, pre-storage and transfer stations, in order to internalize managing and planning the transport routes [16]. ("Fig. 1")

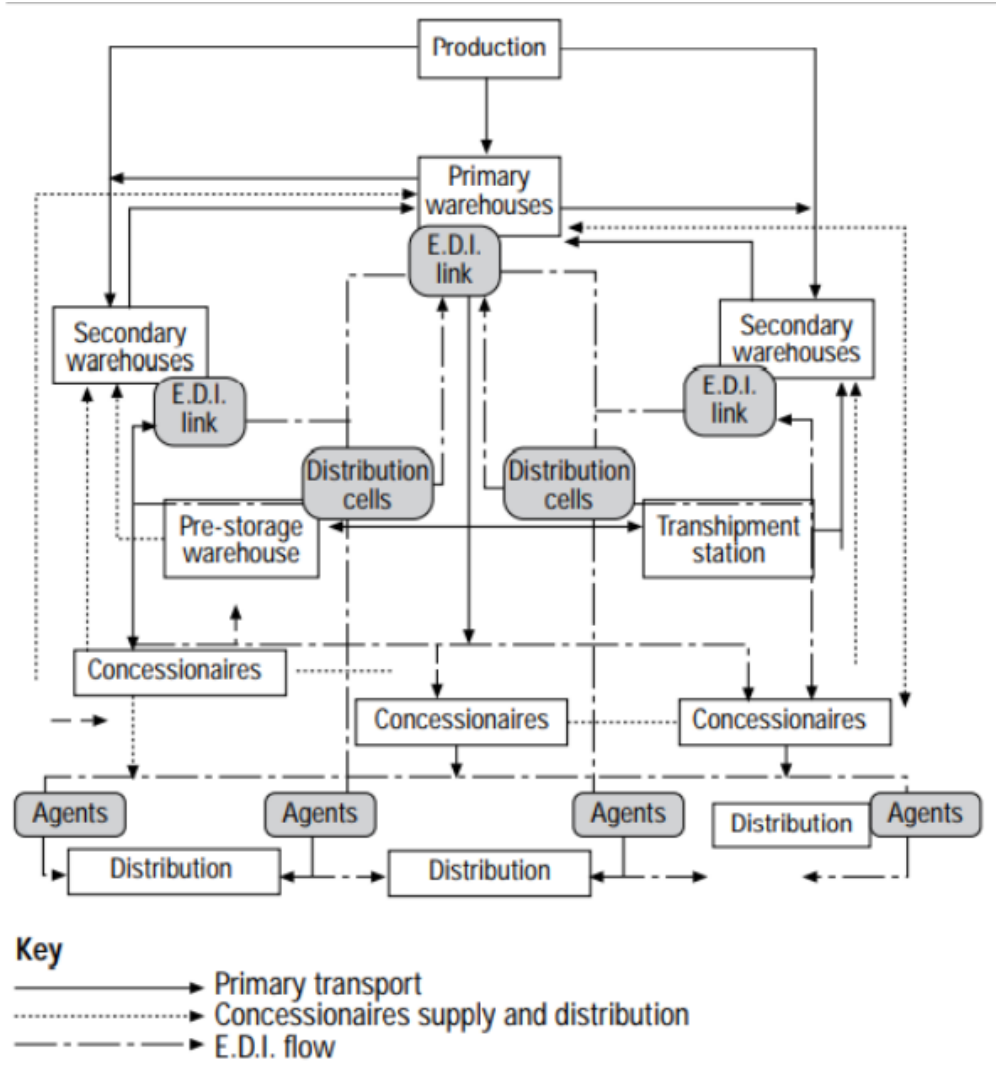

Sourcc: Adapted from Calza and Passaro, 1994

Fig. 1. An interpretation of Unilever-Sagits supply chain management.

\section{Opportunities and challenges}

From the external environment, Unilever's opportunities and threats coexist; but from the internal environment, Unilever's great management, stable financial situation and good image make it advantages outweigh its disadvantages, and that is why Unilever has always been a leader in the consumer product industry. The outbreak of Covid-19 in 2020 makes consumer products in great demand and Unilever's sales did not drop too much in the first-half year due to this pushing. More importantly, among a number of consumer products, Unilever's are differentiated, allowing consumers to recognize the quality and be willing to bear the corresponding prices. However, this does not mean that with adopting a differentiated 
strategy, Unilever does not need to consider the threats brought by the rise of local companies. For example, in China, the standardized management of the tea market and the rationalization of pricing have made local tea more and more popular, so Unilever's tea brand Lipton's sales and profit margins have dropped significantly. At the same time, coupled with the ever-changing trade policies of the United States and the international exchange rates of Pound and Euro due to Brexit, Unilever faces huge challenges in its transactions. However, as an international company which has been in business for nearly 200 years, Unilever's own stable financial status and excellent leadership team give it sufficient risk management capabilities; and in terms of products, Unilever's differentiated strategy in product sales allows Unilever to have a foundation in consumers. That means even if Unilever would make some strategic adjustments in the future, it still has a stable customer base. Hence, for its great power and strengths, though facing changing external environment, Unilever still has opportunities to develop in the future.

\section{CONCLUSION}

Although the external environment poses great challenges to Unilever, the accumulated brand image and consumer accumulation of Unilever in various markets for many years are enough to help Unilever overcome the difficulties. Similarly, in the face of uncertainties in the international situation, Unilever's operations in multiple countries is an effective way to reduce risks. Therefore, although Unilever faces certain and uncertain threats at this time, there is still enough confidence to believe that Unilever has the ability to resist threats. In addition, its continuous innovation and sustainable development strategy can give Unilever much space to develop in the future.

\section{References}

[1] J. A. Czepiel, R. A. Kerin, Competitor analysis, in: Handbook of marketing strategy, 2012, pp.528. DOI: https://doi.org/10.4337/9781781005224

[2] G. Jones, P. Miskell, European integration and corporate restructuring: the strategy of Unilever, c. 1957-c. 19901, in: The Economic History Review, 2005, pp.113-139. DOI: https://doi.org/10.1111/j.1468-0289.2005.00300.x

[3] P. T. Sandvik, E. Storli, Big business and small states: Unilever and Norway in the interwar years1, in: The Economic History Review, 2013, pp.109-131. DOI: https://doi.org/10.1111/j.14680289.2012.00660.x

[4] MD Mishler, Currency turmoil, price, and profit in global markets: How to manage the risks of volatile foreign currency exchange rates, in: Journal of Accountancy, 2017, Vol. 223, No. 3

[5] H. J. Wilson, P. R. Daugherty, Collaborative intelligence: humans and AI are joining forces, in: Harvard Business Review, 2018
[6] G. M. Maina, Influence of organizational and technology factors on Digital Media integration in new product launch projects. A case of Unilever, Kenya, 2017

[7] L. Ma, Financial Analysis of Unilever Company, 2017

[8] M. R. Ahmed, The RACI Matrix and its implications: a case of Unilever, 2019

[9] F. A. Maljers, Inside Unilever: The evolving transnational company, in: Harvard Business Review, 1992

[10] M. Hitt, J. Harrison, R. D. Ireland, A. Best, Attributes of successful and unsuccessful acquisitions of US firms, in: British Journal of Management,1998 pp.91-114. DOI:https://doi.org/10.1111/1467-8551.00077

[11] A. O. Patrick, Unilever chief increases sales, but profit margins suffer, in: Wall Street Journal, August 7-9, p. 5.

[12] J. I. Dirisu, O. Iyiola, O. S. Ibidunni, Product differentiation: A tool of competitive advantage and optimal organizationa performance (A study of Unilever Nigeria PLC), European Scientific Journal, 2013, vol.9, No.34

[13] Y. Ze, H. Abbas, T. Hussain, H. Jiao, Analyzing the differentiation strategies of big companies competing with each other, in: Strategic Management, 2018, vol. 23, br. 3, str. 25-37, DOI:10.5937/StraMan18030252

[14] S.U. Haque, Y. Jahan, R. Siddique, T. Tasnim, S. Roy, Marketing Analysis of Unilever, in: Total Quality Management, 2015

[15] K. Raj, P. S. Aithal, A. 'Desi'Multinational-A Case Study of Hindustan Unilever Limited, in: in: International Journal of Engineering Research and Modern Education (IJERME), volume 2, issue 1, pp. 16-27

[16] F. Calza, R. Passaro, EDI network and logistics management at Unilever-Sagit, in: Supply Chain Management, 1997, Vol. 2 No. 4, pp. 158-170, DOI: https://doi.org/10.1108/13598549710191322

\section{DOI:}

